\title{
The Whole "Kitten"-Caboodle: Perceived Differences in Veterinary and General Population Opinions Regarding Cat Behavior and Health
}

\author{
Courtney Bir ${ }^{*}$, Nicole J. Olynk Widmar ${ }^{1}$, Candace C. Croney ${ }^{2}$ \\ ${ }^{1}$ Dept. of Agricultural Economics, Purdue University, West Lafayette, USA \\ ${ }^{2}$ Purdue University College of Veterinary Medicine, West Lafayette, USA \\ Email: *birc@purdue.edu
}

How to cite this paper: Bir, C., Widmar, N.J.O. and Croney, C.C. (2016) The Whole "Kitten"-Caboodle: Perceived Differences in Veterinary and General Population Opinions Regarding Cat Behavior and Health. Open Journal of Veterinary Medicine, 6, 177-192. http://dx.doi.org/10.4236/ojvm.2016.612021

Received: November 15, 2016

Accepted: December 27, 2016

Published: December 30, 2016

Copyright $\odot 2016$ by authors and Scientific Research Publishing Inc. This work is licensed under the Creative Commons Attribution International License (CC BY 4.0).

http://creativecommons.org/licenses/by/4.0/ (c) (i) Open Access

\section{Abstract}

People's attitudes towards animals are likely to impact their quality of care offered. Understanding perceptions of cats is important to identify potential cat welfare issues and to facilitate best care practices. An online survey was developed to gather information from 1172 U.S. residents on perceptions of cats and sources of cat welfare information. Demographic variables, information regarding respondents' characterization, knowledge and beliefs of cats, their behavior, and welfare needs were collected. A subsample of cat owning households was surveyed regarding their opinions on cat behavior. Veterinarians were also surveyed to determine if they differed from general respondents in their views of and knowledge of cats and their care. The highest percentage of respondents in both groups identified veterinarians as the most accessible (52\% veterinarian, $29 \%$ general public respondents) and most credible sources (veterinarians $76 \%$, general public $29 \%$ ) of information on cat behavior. In response to being asked about acceptable reasons to relinquish cats, more general respondents selected "convenience" (13\% veterinarians, 3\% general population). Several inconsistencies in perceptions and practices between and within members of the general public and veterinarians were observed. General respondents and veterinarians both indicated a lack of confidence in addressing behavioral issues in cats. Both groups disagreed that they (in the case of veterinarians) or their veterinarians provided useful resources on cat behavior or health. Opportunities exist for improvement in consistency between knowledge, attitudes and practices or services relative to cats. Improved competence and information transfer on both the behavioral and 
physical health aspects of cat welfare are also needed.

\section{Keywords}

Cat, Behavior, Welfare, Veterinarian, Perceptions

\section{Introduction}

From the reverent attitude towards cats of the ancient Egyptians, to the fear, superstition and association with witchcraft and the devil from the $12^{\text {th }}$ through $17^{\text {th }}$ centuries, the change in popular opinion of cats over time has been drastic [1]. Although cats are now the most commonly kept companion animals in the U.S. today, surpassing even the number of dogs, people's attitudes towards them appear to be ambivalent [2]. Respondents to a survey conducted by Kellert and Berry [3] revealed that $17.4 \%$ of respondents expressed some level of animosity to cats, although only $2.6 \%$ indicated similar feelings about dogs. Likewise, Perrine and Osbourne [4] observed more aversion towards cats than dogs, with $18 \%$ of their respondents reporting they disliked cats, whereas less than $2 \%$ disliked dogs. These findings are surprising given people consistently report benefits of cat ownership such as affection and personality [5]. Further, lack of information on cats, particularly relative to behavior, has been cited as a major risk factor for cat relinquishment [6] [7].

People's attitudes to animals are likely to have implications for their perceived obligations towards and the corresponding quality of care and welfare offered [8] [9]. Thus, it is important to understand perceptions relative to cats and their needs by the general public and veterinarians. Veterinarians have an interest in the general climate of opinions regarding cats, as this may impact people's willingness to seek care. The goal of this analysis was to explore the general population's attitudes, knowledge and perceptions relative to cats, their behavior and welfare needs, and to compare their opinions to a convenience sample of veterinarians.

\section{Materials and Methods}

\section{Survey Instrument and Data Collection}

An online survey in Qualtrics was used to gather information in April, 2016 from a sample of 1172 U.S. residents. The survey was designed to collect demographic information as well as respondents' beliefs about cats, their behavior, and care needs. The survey also included questions specifically for the subsample of cat owning households regarding their opinions on cat behavior, as well as their veterinarians' aptitude for identifying and providing information about the behavioral and physical needs of their cats. U.S. resident survey respondents were obtained using a large opt-in database by Light speed GMI. The sample of U.S. residents was targeted to be representative of the U.S. resident population in 
terms of gender, income, education, and geographical region of residence, [10] [11] [12]. Regions of residence were defined as in the Census Bureau Regions and Divisions. ${ }^{1}$ Respondents were required to be at least 18 years of age.

A convenience sample of veterinarians was obtained by sending a paper survey with a postage paid response envelope or the option to answer online to veterinary clinics within a 100-mile radius of Purdue University. Additionally, surveys were made available at the Purdue University Veterinary Teaching Hospital. Nine hundred and two surveys were mailed to veterinary clinics, and 100 surveys were made available at Purdue. A degree in veterinary medicine was required for participation. In total, 193 surveys were returned for a response rate of $19.26 \%$. Some veterinarians did not answer all questions, so each question was evaluated individually with the total responses provided by question in the results tables. The veterinarian survey was designed to collect demographic information as well as respondents' beliefs about cats, cat behavior, and cat needs. The veterinarian survey also included questions regarding procedures/treatments for cats often performed/recommended.

\section{Summary Statistics and Fisher Exact test of Categorical Variables}

The data were summarized by calculating the frequency of categorical variables and means of continuous variables. For categorical variables Stata [13] was used to conduct the Fisher exact test, a variation of the chi-squared test, to determine if the responses across samples and/or subsamples were statistically different. Due to multiple responses by veterinarians, it was not possible to statistically test responses to the questions: "Most accessible information source on cat behavior", "Most trusted source of information on cat behavior", and "Cats are".

\section{T-Test of Likert Scale Questions}

Likert-scale questions (on a scale of 1 (strongly agree) to 7 (strongly disagree)) were used to measure the level of agreement by veterinarians and the general population with statements concerning cats, their behaviors and needs. A selection of 3 or less indicated agreement, a selection of 4 indicated neutrality, and a selection of 5 or more indicated disagreement. The statements were worded to have the same meaning for both veterinarians and the general public, but were tailored for each group. Using Welch's T-test, assuming unequal variances, the means of the responses from veterinarians and the general population were compared to determine if they were statistically different using Stata [13]. Although the two groups may both be more toward the agree or disagree side of the continuum from agree to disagree, their mean level of agreement may be statistically different.

\section{Results}

\section{Demographics and clinical services}

Table 1 presents demographics for the general population, and for the veteri-

\footnotetext{
${ }^{1}$ Regions were defined, according to the U.S. Census Bureau (2012).
} 
narians surveyed. Table 2 presents additional veterinarian specific demographics. Veterinarians graduated from 28 different universities and the majority worked in small animal practice. On average, cats made up 30\% of their patients and provided $24 \%$ of their revenue. Multiple selections of procedures/treatments recommended for cats were allowed and the most frequently selected treatments/procedures recommended by veterinarians were vaccines and preventative flea medication, dental cleanings, food recommendations and wellness visits. The least recommended procedures/treatments were socialization, and "happy visits" (counter-conditioning and desensitization to clinic visits).Categorical responses to questions presented to both samples were compared using the Fisher's exact test, and are presented in Table 3.

Table 1. Demographics of general population and veterinary respondents.

\begin{tabular}{|c|c|c|c|}
\hline Question & $\begin{array}{l}\text { General Population } \\
\text { Percent (\%) of All } \\
\text { Respondents } \\
\text { n }=1172\end{array}$ & $\begin{array}{c}\text { General Population } \\
\text { Percent (\%) of } \\
\text { Respondents Reportedly } \\
\text { Owning a Cat } n=465\end{array}$ & $\begin{array}{l}\text { Veterinarian } \\
\text { Percent (\%) of } \\
\text { Respondents to } \\
\text { Each Question }\end{array}$ \\
\hline Age & & & $\mathrm{n}=185$ \\
\hline $18-24$ & $11 \%$ & $12 \%$ & $0 \%$ \\
\hline $25-34$ & $15 \%$ & $20 \%$ & $30 \%$ \\
\hline $35-44$ & $18 \%$ & $25 \%$ & $24 \%$ \\
\hline $45-54$ & $18 \%$ & $17 \%$ & $19 \%$ \\
\hline $55-65$ & $20 \%$ & $16 \%$ & $21 \%$ \\
\hline $66-88$ & $18 \%$ & $10 \%$ & $\begin{array}{c}6 \% \\
\mathrm{n}=182\end{array}$ \\
\hline Number of adults in my family & 2.04 & 2.11 & $\begin{array}{c}1.89 \\
\mathrm{n}=140\end{array}$ \\
\hline Number of children in my family & 0.82 & 0.99 & 1.51 \\
\hline \multicolumn{4}{|l|}{ Educational Background } \\
\hline Did not graduate from high school & $2 \%$ & $2 \%$ & - \\
\hline Graduated from high school, did not attend college & $24 \%$ & $21 \%$ & - \\
\hline Attended college, no degree earned & $27 \%$ & $28 \%$ & - \\
\hline $\begin{array}{l}\text { Attended college, bachelor's (B.S. or B.A.), associates or } \\
\text { trade degree earned }\end{array}$ & $30 \%$ & $32 \%$ & - \\
\hline Graduate or advanced degree (M.S., Ph.D., Law school) & $17 \%$ & $18 \%$ & - \\
\hline \multicolumn{4}{|l|}{ Region of Residence } \\
\hline Northeast & $20 \%$ & $20 \%$ & - \\
\hline South & $32 \%$ & $34 \%$ & - \\
\hline Midwest & $24 \%$ & $19 \%$ & - \\
\hline West & $24 \%$ & $27 \%$ & - \\
\hline
\end{tabular}


Table 2. Demographics of veterinarian respondents.

\begin{tabular}{|c|c|}
\hline Demographic Variable & \\
\hline Number of Years in Practice (Average) $(n=189)$ & 16 \\
\hline & $\begin{array}{l}\text { Percent (\%) of Respondents } \\
\text { to Each Question }\end{array}$ \\
\hline \multicolumn{2}{|l|}{ Type of Practice $(\mathrm{n}=187)$} \\
\hline Large Animal & $3 \%$ \\
\hline Small Animal & $86 \%$ \\
\hline Exotics & $2 \%$ \\
\hline Mixed Practice & $10 \%$ \\
\hline \multicolumn{2}{|l|}{ Percent of Practice that are cats } \\
\hline Total patients $(\mathrm{n}=186)$ & $30 \%$ \\
\hline Total Revenue $(\mathrm{n}=176)$ & $24 \%$ \\
\hline \multicolumn{2}{|l|}{ Procedure/Treatment for cats recommended by veterinarians } \\
\hline Vaccinations $(\mathrm{n}=177)$ & $97 \%$ \\
\hline Fecal Exams $(n=165)$ & $90 \%$ \\
\hline Low stress Handling $(\mathrm{n}=148)$ & $81 \%$ \\
\hline Wellness visits $(\mathrm{n}=166)$ & $91 \%$ \\
\hline Socialization $(\mathrm{n}=72)$ & $39 \%$ \\
\hline $\begin{array}{l}\text { "Happy visits" (counter-conditioning and desensitization to } \\
\text { clinic visits) }(\mathrm{n}=56)\end{array}$ & $31 \%$ \\
\hline Preventative Heartworm Medication $(\mathrm{n}=118)$ & $64 \%$ \\
\hline Preventative Flea Medication $(\mathrm{n}=177)$ & $97 \%$ \\
\hline Dental Cleanings $(\mathrm{n}=175)$ & $96 \%$ \\
\hline Food Recommendations $(\mathrm{n}=166)$ & $91 \%$ \\
\hline Behavior advice $(\mathrm{n}=147)$ & $80 \%$ \\
\hline
\end{tabular}

\section{Characterizations and sources of information on cats}

To better understand people's expectations of cats, respondents who owned cats were asked why they had chosen to keep one (Table 3). The most commonly given reasons were "I like their physical appearance" and "they are relatively easy to care for". Characterizations of cats that indirectly may reflect the level of attachment to them were captured by responses to the statement, "cats are". Both groups most frequently characterized cats as "a member of the family", followed by "a pet”, and "an animal".

The most accessible information source on cat behavior was most frequently perceived as "a veterinarian" by both veterinarians and the general population (Table 4). Likewise, both groups selected a veterinarian as the most trusted source of information on cat behavior. 
Table 3. Demographic and categorical cat question analysis for veterinarian responses and general population respondents.

\begin{tabular}{cccc}
\hline Statement & $\begin{array}{c}\text { Percent of } \\
\text { Veterinarian } \\
\text { Responses }\end{array}$ & $\begin{array}{c}\text { Percent of General } \\
\text { Population } \\
\text { Respondents }\end{array}$ & P-Value \\
\hline I am female & $\mathrm{n}=183$ & $\mathrm{n}=1172$ & \\
& $69 \%$ & $55 \%$ & 0.000
\end{tabular}

Annual pre-tax household income

$\begin{array}{cccc}\mathrm{n}=172 & \mathrm{n}=1172 & \\ \$ 0-\$ 25,000 & 1 \% & 21 \% & 0.000 \\ \$ 26,000-\$ 50,000 & 6 \% & 25 \% & 0.000 \\ \$ 51,000-\$ 75,000 & 11 \% & 19 \% & 0.000 \\ \$ 76,000-\$ 100,000 & 17 \% & 13 \% & 0.000 \\ \$ 101,000 \text { and higher } & 65 \% & 22 \% & 0.000\end{array}$

Do you own a pet

$\begin{array}{cccc} & \mathrm{n}=176 & \mathrm{n}=1172 & \\ \text { No } & 6 \% & 34 \% & 0.000 \\ \text { Yes } & 94 \% & 66 \% & 0.000\end{array}$

The number of animals you currently have in your household

$\begin{array}{cccc} & \mathrm{n}=166 & \mathrm{n}=773 & \\ \text { No dogs } & 12 \% & 29 \% & 0.000 \\ \text { No Cats } & 15 \% & 40 \% & 0.000 \\ \text { No Horses } & 45 \% & 96 \% & 0.000 \\ \text { No Fish } & 45 \% & 86 \% & 0.000 \\ \text { No Birds } & 57 \% & 89 \% & 0.000 \\ \text { No Reptiles } & 58 \% & 95 \% & 0.000 \\ \text { No Small Mammals } & 51 \% & 91 \% & 0.000\end{array}$

It is acceptable to relinquish a cat for:

$\begin{array}{cccc} & \mathrm{n}=184 & \mathrm{n}=1172 & \\ \text { Behavioral reason } & 69 \% & 27 \% & 0.000 \\ \text { Convenience } & 3 \% & 13 \% & 0.000 \\ \text { It is never acceptable to relinquish a cat } & 16 \% & 37 \% & 0.000 \\ \text { Health reasons } & 55 \% & 14 \% & 0.009 \\ \text { Other } & 27 \% & 14 \% & 0.000\end{array}$

Reasons why respondents chose a cat as a pet (cat owners only)

\begin{tabular}{cccc} 
& $\mathrm{n}=108$ & $\mathrm{n}=465$ & \\
I like their physical appearance & $70 \%$ & $60 \%$ & 0.048 \\
I am allergic to other types of pets & $1 \%$ & $8 \%$ & 0.007 \\
I feel they are easier to care for & $71 \%$ & $65 \%$ & 0.215 \\
I don't have the space for other larger pets & $11 \%$ & $14 \%$ & 0.441 \\
I feel they are a relatively less expensive pet & $10 \%$ & $27 \%$ & 0.000 \\
\hline
\end{tabular}


Table 4. Statements regarding cats and sources of cat behavior information.

\begin{tabular}{|c|c|c|c|}
\hline Statement & $\begin{array}{c}\text { Percent of } \\
\text { Veterinary } \\
\text { Respondents }^{1}\end{array}$ & $\begin{array}{l}\text { Percent of } \\
\text { Veterinary } \\
\text { Selections }{ }^{2}\end{array}$ & $\begin{array}{c}\text { Percent of General } \\
\text { Population } \\
\text { Respondents }\end{array}$ \\
\hline $\begin{array}{l}\text { Most accessible information source on cat } \\
\text { behavior }\end{array}$ & $\mathrm{n}=184$ & $\mathrm{n}=349$ & $\mathrm{n}=1172$ \\
\hline A veterinarian & $52 \%$ & $28 \%$ & $29 \%$ \\
\hline ASPCA & $13 \%$ & $7 \%$ & $10 \%$ \\
\hline AVMA & $16 \%$ & $8 \%$ & $4 \%$ \\
\hline HSUS & $7 \%$ & $3 \%$ & $3 \%$ \\
\hline 4-H Leaders & $5 \%$ & $3 \%$ & $1 \%$ \\
\hline Breeders & $10 \%$ & $5 \%$ & $2 \%$ \\
\hline Friends/neighbors & $33 \%$ & $17 \%$ & $7 \%$ \\
\hline Local Humane Societies/shelters & $12 \%$ & $6 \%$ & $7 \%$ \\
\hline AHA & $2 \%$ & $1 \%$ & $4 \%$ \\
\hline University Scientists/Researchers & $13 \%$ & $3 \%$ & $2 \%$ \\
\hline PETA & $5 \%$ & $3 \%$ & $3 \%$ \\
\hline Other & $27 \%$ & $14 \%$ & $1 \%$ \\
\hline $\begin{array}{l}\text { I do not have a source for cat welfare/humane } \\
\text { treatment information }\end{array}$ & $2 \%$ & $1 \%$ & $27 \%$ \\
\hline $\begin{array}{c}\text { Most trusted source of information on cat } \\
\text { behavior }\end{array}$ & $\mathrm{n}=185$ & $\mathrm{n}=340$ & $\mathrm{n}=1172$ \\
\hline A veterinarian & $76 \%$ & $41 \%$ & $29 \%$ \\
\hline ASPCA & $7 \%$ & $4 \%$ & $9 \%$ \\
\hline AVMA & $39 \%$ & $21 \%$ & $7 \%$ \\
\hline HSUS & $4 \%$ & $2 \%$ & $4 \%$ \\
\hline 4-H Leaders & $1 \%$ & $0 \%$ & $1 \%$ \\
\hline Breeders & $2 \%$ & $1 \%$ & $2 \%$ \\
\hline Friends/neighbors & $2 \%$ & $1 \%$ & $5 \%$ \\
\hline Local Humane Societies/shelters & $2 \%$ & $1 \%$ & $6 \%$ \\
\hline AHA & $3 \%$ & $2 \%$ & $3 \%$ \\
\hline University Scientists/Researchers & $23 \%$ & $12 \%$ & $3 \%$ \\
\hline PETA & $0 \%$ & $0 \%$ & $4 \%$ \\
\hline Other & $22 \%$ & $12 \%$ & $1 \%$ \\
\hline $\begin{array}{l}\text { I do not have a source for cat welfare/humane } \\
\text { treatment information }\end{array}$ & $3 \%$ & $2 \%$ & $26 \%$ \\
\hline \multicolumn{4}{|l|}{ Cats are: } \\
\hline & $\mathrm{n}=189$ & $\mathrm{n}=208$ & $\mathrm{n}=1172$ \\
\hline An animal & $13 \%$ & $12 \%$ & $15 \%$ \\
\hline A member of the family & $56 \%$ & $50 \%$ & $41 \%$ \\
\hline A working animal & $0 \%$ & $0 \%$ & $1 \%$ \\
\hline A child & $1 \%$ & $0 \%$ & $3 \%$ \\
\hline A pet & $41 \%$ & $37 \%$ & $39 \%$ \\
\hline A potential source of income & $1 \%$ & $0 \%$ & $1 \%$ \\
\hline
\end{tabular}

${ }^{1}$ The percent of veterinary respondents is the number of veterinarians who selected the answer choice divided by the number of veterinarians who responded to the question multiplied by $100 ;{ }^{2}$ The percent of veterinary selection is the number of selections for the answer choice divided by the total number of selections made for that question (multiple answer choices were selected) multiplied by 100 . 


\section{Beliefs about cats}

A higher percentage of veterinarians selected behavioral reasons, health reasons, and "other" than general population respondents as acceptable reasons to relinquish a cat (Table 3). More general population respondents selected "convenience", and "it is never acceptable" than veterinarians. Respondents were asked to indicate on a Likert scale their level of agreement regarding beliefs about cats (Table 5). For the statement, "Cats have less social needs than other animals", veterinarians were toward disagree, while the general population was toward agree. For the statements "It is difficult to interpret cat behavior", "Cats tolerate pain well", and "Cats are less expensive to maintain than other animals", the general public showed higher agreement with these statements. For the statements, "Cats are friendly", and "Cats need to visit a veterinarian regularly", both veterinarians and the general population were toward agree, with veterinarians indicating stronger agreement. Veterinarians also agreed more than the general population with the statement, "Cats are good with children".

\section{Knowledge of cats' needs}

For the statements, "Cats need an area where they can be elevated to feel safe", "Cats need areas where they can hide", "Cats need regular one on one interactions with people", "It is important to alleviate pain in cats", "Cats require socialization", "Cats are easily distressed by disruptions (noise, change in routine or caretakers)", "Disruptions to the cat's routine can result in sickness or behavior problems", and "Cats need to go on practice runs to the veterinarian", both the general public's and veterinarians' mean responses were more toward agree, but veterinarians agreed more (Table 6 and Table 7). Veterinarians disagreed more with the statements, "Cats need access to the outdoors", "It is easy to see when cats are in pain", and "It is more important to address cats' physical needs than their behavioral needs" when compared to the general population.

\section{Attitudes and confidence related to meeting cats' needs}

Statements regarding people's attitudes and confidence relative to cat/ veterinarian interactions were shown to both groups (Table 8). Veterinarians and the general population had indistinguishable responses to the statements, "If a [my] cat has a behavioral problem I am confident that I [my vet] will know how to address it" and "I [my vet] provide[s] useful resources on cat behavior". Veterinarians agreed more with the statements, "If a [my] cat has a health problem I am confident that I [my vet] will know how to address it", "I [My vet] provide[s] useful resources on cat health", "I [My vet seems to] enjoy working with and handling cats", "I am willing to tolerate or work with clients' [my] cats on behavior problems (e.g., urinating outside the litterbox)" when compared to the general population. The general population agreed more with the statements, "I am willing to tolerate or work with clients' [my] cats on behavior problems (e.g., aggression toward people or others in the household)". Veterinarians disagreed more with the statement, "If a cat is fractious or difficult to handle during an 
Table 5. Veterinarian and general population beliefs about cats.

\begin{tabular}{|c|c|c|c|}
\hline Statement & $\begin{array}{c}\text { Veterinarian } \\
\text { Mean }^{1} \text { (S.D.) } \\
\text { Response }\end{array}$ & $\begin{array}{l}\text { General Population } \\
\text { Mean }^{1} \text { (S.D.) } \\
\text { Response } n=1172\end{array}$ & P-Value \\
\hline Cats have less social needs than other animals & $\begin{array}{c}5.17 \\
(0.12) \\
\mathrm{n}=185\end{array}$ & $\begin{array}{c}3.64 \\
(1.83)\end{array}$ & 0.0000 \\
\hline Cats can't be trained & $\begin{array}{c}5.95 \\
(1.27) \\
\mathrm{n}=187\end{array}$ & $\begin{array}{c}4.60 \\
(1.91)\end{array}$ & 0.0000 \\
\hline Cats are friendly & $\begin{array}{c}2.18 \\
(1.15) \\
\mathrm{n}=184\end{array}$ & $\begin{array}{c}2.99 \\
(1.63)\end{array}$ & 0.0000 \\
\hline $\begin{array}{l}\text { Cats are lonely without other cats as } \\
\text { companions in the home }\end{array}$ & $\begin{array}{c}4.81 \\
(1.56) \\
\mathrm{n}=187\end{array}$ & $\begin{array}{c}4.11 \\
(1.77)\end{array}$ & 0.0067 \\
\hline Cats are loyal & $\begin{array}{c}2.96 \\
(1.41) \\
\mathrm{n}=186\end{array}$ & $\begin{array}{c}3.10 \\
(1.75)\end{array}$ & 0.2418 \\
\hline Cats are good with children & $\begin{array}{c}2.89 \\
(1.10) \\
\mathrm{n}=186\end{array}$ & $\begin{array}{c}3.27 \\
(1.62)\end{array}$ & 0.0020 \\
\hline Cats are independent & $\begin{array}{c}2.21 \\
(1.23) \\
\mathrm{n}=187\end{array}$ & $\begin{array}{c}2.59 \\
(1.78)\end{array}$ & 0.0044 \\
\hline Cats need to visit a veterinarian regularly & $\begin{array}{c}1.41 \\
(1.02) \\
\mathrm{n}=188\end{array}$ & $\begin{array}{c}2.83 \\
(1.81)\end{array}$ & 0.0000 \\
\hline Cats are spiteful & $\begin{array}{c}5.49 \\
(1.52) \\
\mathrm{n}=189\end{array}$ & $\begin{array}{c}4.30 \\
(1.84)\end{array}$ & 0.0000 \\
\hline Cats are difficult to handle & $\begin{array}{c}4.57 \\
(1.44) \\
\mathrm{n}=188\end{array}$ & $\begin{array}{c}4.54 \\
(1.84)\end{array}$ & 0.8310 \\
\hline It is difficult to interpret cat behavior & $\begin{array}{c}4.38 \\
(1.63) \\
\mathrm{n}=188\end{array}$ & $\begin{array}{c}3.91 \\
(1.78)\end{array}$ & 0.0006 \\
\hline Cats tolerate pain well & $\begin{array}{c}4.46 \\
(1.71) \\
\mathrm{n}=188\end{array}$ & $\begin{array}{c}4.11 \\
(1.70)\end{array}$ & 0.0094 \\
\hline $\begin{array}{l}\text { Cats are less expensive to maintain than other } \\
\text { animals }\end{array}$ & $\begin{array}{c}3.84 \\
(1.69) \\
\mathrm{n}=188\end{array}$ & $\begin{array}{c}3.45 \\
(1.69)\end{array}$ & 0.0053 \\
\hline
\end{tabular}

${ }^{1}$ The mean response was calculated by taking the average of the likert scale responses to that statement which ranged from 1 to 7 . 
Table 6. Veterinarian and general population level of agreement on cat needs.

\begin{tabular}{|c|c|c|c|}
\hline Statement & $\begin{array}{l}\text { Veterinarian } \\
\text { Mean }^{1} \\
\text { Response } \\
\text { (S.D.) }\end{array}$ & $\begin{array}{c}\text { General } \\
\text { Population Mean } \\
\text { Response (S.D.) } \\
\text { n }=1172\end{array}$ & P-Value \\
\hline $\begin{array}{l}\text { Cats need an area where they can be elevated to feel } \\
\text { safe }\end{array}$ & $\begin{array}{c}2.09 \\
(1.20) \\
\mathrm{n}=186\end{array}$ & $\begin{array}{c}2.91 \\
(1.64)\end{array}$ & 0.0000 \\
\hline It is acceptable for cats to roam freely outdoors & $\begin{array}{c}4.54 \\
(1.93) \\
\mathrm{n}=187\end{array}$ & $\begin{array}{c}4.26 \\
(2.04)\end{array}$ & 0.1025 \\
\hline Cats need areas where they can hide & $\begin{array}{c}1.67 \\
(.97) \\
\mathrm{n}=188\end{array}$ & $\begin{array}{c}2.75 \\
(1.66)\end{array}$ & 0.0000 \\
\hline Cats need to go on practice runs to the veterinarian & $\begin{array}{c}3.09 \\
(1.41) \\
\mathrm{n}=188\end{array}$ & $\begin{array}{c}3.91 \\
(1.73)\end{array}$ & 0.0000 \\
\hline Cats need access to the outdoors & $\begin{array}{c}4.55 \\
(1.80) \\
\mathrm{n}=168\end{array}$ & $\begin{array}{c}3.78 \\
(1.94)\end{array}$ & 0.0000 \\
\hline Cats should be fed wet food & $\begin{array}{c}3.61 \\
(1.67) \\
\mathrm{n}=188\end{array}$ & $\begin{array}{c}3.61 \\
(1.59)\end{array}$ & 0.9723 \\
\hline Cats should be fed dry food & $\begin{array}{c}3.17 \\
(1.47) \\
\mathrm{n}=188\end{array}$ & $\begin{array}{l}3.25 \\
(1.53)\end{array}$ & 0.4790 \\
\hline Cats need a companion cat ("a friend") & $\begin{array}{c}4.35 \\
(1.48) \\
\mathrm{n}=188\end{array}$ & $\begin{array}{r}3.80 \\
(1.71)\end{array}$ & 0.0000 \\
\hline Cats need regular one on one interactions with people & $\begin{array}{c}2.22 \\
(1.24) \\
\mathrm{n}=88\end{array}$ & $\begin{array}{c}2.92 \\
(1.67)\end{array}$ & 0.0000 \\
\hline Cats in shelters should be group housed & $\begin{array}{c}3.89 \\
(1.41) \\
\mathrm{n}=185\end{array}$ & $\begin{array}{c}3.76 \\
(1.54)\end{array}$ & 0.2819 \\
\hline
\end{tabular}

${ }^{1}$ The mean response was calculated by taking the average of the likert scale responses to that statement which ranged from 1 to 7 . 
Table 7. Veterinarian and general population level of agreement on cat needs continued.

\begin{tabular}{|c|c|c|c|}
\hline Statement & $\begin{array}{l}\text { Veterinarian } \\
\text { Mean }^{1} \\
\text { Response } \\
\text { (S.D.) }\end{array}$ & $\begin{array}{c}\text { General } \\
\text { Population Mean } \\
\text { Response (S.D.) } \\
\text { n }=1172\end{array}$ & P-Value \\
\hline Cats require socialization & $\begin{array}{c}1.96 \\
(1.13) \\
\mathrm{n}=189\end{array}$ & $\begin{array}{c}3.12 \\
(1.60)\end{array}$ & 0.0000 \\
\hline Cats need mental stimulation & $\begin{array}{c}1.51 \\
(0.96) \\
\mathrm{n}=189\end{array}$ & $\begin{array}{c}2.90 \\
(1.65)\end{array}$ & 0.0000 \\
\hline Cats need exercise & $\begin{array}{c}1.48 \\
(0.88) \\
\mathrm{n}=189\end{array}$ & $\begin{array}{c}2.61 \\
(1.70)\end{array}$ & 0.0000 \\
\hline $\begin{array}{l}\text { Cats are easily distressed by disruptions (noise, change } \\
\text { in routine or caretakers) }\end{array}$ & $\begin{array}{c}2.05 \\
(1.19) \\
\mathrm{n}=186\end{array}$ & $\begin{array}{c}3.06 \\
(1.58)\end{array}$ & 0.0000 \\
\hline $\begin{array}{l}\text { Disruptions to the cat's routine can result in sickness } \\
\text { or behavior problems }\end{array}$ & $\begin{array}{c}1.85 \\
(1.02) \\
\mathrm{n}=189\end{array}$ & $\begin{array}{c}3.15 \\
(1.56)\end{array}$ & 0.0000 \\
\hline I seek out information on cat health & $\begin{array}{c}2.06 \\
(1.33) \\
\mathrm{n}=189\end{array}$ & $\begin{array}{c}4.35 \\
(2.14)\end{array}$ & 0.0000 \\
\hline I seek out information on cat behavior & $\begin{array}{c}2.31 \\
(1.42) \\
\mathrm{n}=189\end{array}$ & $\begin{array}{c}4.40 \\
(2.15)\end{array}$ & 0.0000 \\
\hline It is easy to see when cats are in pain & $\begin{array}{c}4.65 \\
(1.59) \\
\mathrm{n}=188\end{array}$ & $\begin{array}{c}3.71 \\
(1.64)\end{array}$ & 0.0000 \\
\hline It is important to alleviate pain in cats & $\begin{array}{c}1.50 \\
(1.06) \\
\mathrm{n}=188\end{array}$ & $\begin{array}{c}2.64 \\
(1.72)\end{array}$ & 0.0000 \\
\hline $\begin{array}{l}\text { It is more important to address cats' physical needs } \\
\text { than their behavioral needs }\end{array}$ & $\begin{array}{c}5.10 \\
(1.52) \\
\mathrm{n}=187\end{array}$ & $\begin{array}{c}3.88 \\
(1.57)\end{array}$ & 0.0000 \\
\hline
\end{tabular}

${ }^{1}$ The mean response was calculated by taking the average of the likert scale responses to that statement which ranged from 1 to 7 . 
Table 8. Level of agreement for veterinarians and the cat owning general population regarding cat veterinarian questions.

\begin{tabular}{|c|c|c|c|c|}
\hline Statement Seen by Veterinarians & $\begin{array}{l}\text { Statement Seen by General } \\
\text { Population cat owners }\end{array}$ & $\begin{array}{l}\text { Veterinarian } \\
\text { Mean }{ }^{1} \text { Response } \\
\text { (S.D.) }\end{array}$ & $\begin{array}{l}\text { General Population } \\
\text { Cat Owner Mean } \\
\text { Response (S.D.) } \\
n=465\end{array}$ & P-Value \\
\hline $\begin{array}{l}\text { If a cat has a behavior problem I am } \\
\text { confident that I will know how to } \\
\text { address }\end{array}$ & $\begin{array}{l}\text { If my cat has a behavior problem I am } \\
\text { confident that my vet will know how to } \\
\text { address it }\end{array}$ & $\begin{array}{c}3.08 \\
(1.43) \\
\mathrm{n}=189\end{array}$ & $\begin{array}{c}3.21 \\
(1.93)\end{array}$ & 0.4183 \\
\hline $\begin{array}{l}\text { If a cat has a health problem I am } \\
\text { confident that I will know how to } \\
\text { address it }\end{array}$ & $\begin{array}{l}\text { If my cat has a health problem I am } \\
\text { confident that my vet will know how to } \\
\text { address it }\end{array}$ & $\begin{array}{c}2.04 \\
(1.44) \\
\mathrm{n}=189\end{array}$ & $\begin{array}{c}2.76 \\
(1.95)\end{array}$ & 0.0000 \\
\hline $\begin{array}{l}\text { I provide useful resources on cat } \\
\text { behavior }\end{array}$ & $\begin{array}{l}\text { My vet provides useful resources on cat } \\
\text { behavior }\end{array}$ & $\begin{array}{c}3.07 \\
(1.63) \\
\mathrm{n}=186\end{array}$ & $\begin{array}{c}3.29 \\
(1.91)\end{array}$ & 0.1813 \\
\hline I provide useful resources on cat health & $\begin{array}{l}\text { My vet provides useful resources on cat } \\
\text { health }\end{array}$ & $\begin{array}{c}2.29 \\
(1.54) \\
\mathrm{n}=186\end{array}$ & $\begin{array}{c}2.91 \\
(1.91)\end{array}$ & 0.0001 \\
\hline I enjoy working with and handling cats & $\begin{array}{l}\text { My vet seems to enjoy working with } \\
\text { cats }\end{array}$ & $\begin{array}{c}2.28 \\
(1.58) \\
\mathrm{n}=187\end{array}$ & $\begin{array}{c}2.74 \\
(1.87)\end{array}$ & 0.0035 \\
\hline $\begin{array}{l}\text { I am willing to tolerate or work with } \\
\text { clients' cats on behavior problems (e.g. } \\
\text { aggression toward people or others in } \\
\text { the household) }\end{array}$ & $\begin{array}{l}\text { I am willing to tolerate or work with my } \\
\text { cat on behavior problems (e.g. } \\
\text { Aggression toward people or others in } \\
\text { the household) }\end{array}$ & $\begin{array}{c}3.00 \\
(1.68) \\
n=188\end{array}$ & $\begin{array}{c}2.70 \\
(1.83)\end{array}$ & 0.0516 \\
\hline $\begin{array}{l}\text { I am willing to tolerate or work with } \\
\text { clients' cats on non-injurious behavior } \\
\text { problems (e.g. urinating outside the } \\
\text { litter box) }\end{array}$ & $\begin{array}{l}\text { I am willing to tolerate or work with my } \\
\text { cat on non-injurious behavior problems } \\
\text { (e.g. urinating outside the litter box) }\end{array}$ & $\begin{array}{c}2.37 \\
(1.67) \\
\mathrm{n}=187\end{array}$ & $\begin{array}{l}2.79 \\
(1.93)\end{array}$ & 0.0097 \\
\hline $\begin{array}{l}\text { If a cat is fractious or difficult to handle } \\
\text { during an exam it is important to use } \\
\text { whatever means (force, restraint) } \\
\text { necessary to complete the exam }\end{array}$ & $\begin{array}{l}\text { If a cat is fractious or difficult to handle } \\
\text { during an exam it is important to use } \\
\text { whatever means (force, restraint) } \\
\text { necessary to complete the exam }\end{array}$ & $\begin{array}{c}5.00 \\
(1.82) \\
\mathrm{n}=187\end{array}$ & $\begin{array}{c}3.56 \\
(1.93)\end{array}$ & 0.0000 \\
\hline
\end{tabular}

${ }^{1}$ The mean response was calculated by taking the average of the likert scale responses to that statement which ranged from 1 to 7.

exam, it is important to use whatever means (force, restraint) necessary to complete the exam" when compared to the general population, who agreed with the statement.

\section{Discussion}

Despite the use of a convenience sample of veterinarians, the sample had variation in Alma matter and was similar demographically to other published surveys of veterinarians. The majority of veterinarians surveyed worked in small animal practices, consistent with AVMA (American Veterinary Medical Association) market research that $74.8 \%$ of veterinary practices are either exclusively or predominantly companion animal focused [14]. The higher percentage found in 
this study may be due to the large urban area included in the geographically limited sample, which also explains the high percentage of Purdue alumni. The percentage of patients and revenue made up by cats is similar to the $26.3 \%$ of time small animal veterinarians spent on cats found by The Center for Health Workforce Studies study for the AVMA [15].

The finding that both veterinarians and members of the public primarily characterized the cat as "a member of the family", followed by "a pet" is consistent with reports of the increasingly important role of pets in families and evolving societal views of them as family members [16] [17]. Such characterizations should bode well for cat welfare as others have reported trends toward better care by owners who view their cats as companions [18]. Our finding that both groups tended to agree that "cats are friendly", and "need to visit a veterinarian regularly" may reflect this tendency. However, several inconsistencies were observed between members of the general public and veterinarians. For example, the treatments/procedures most frequently recommended by veterinarians in this study generally agree with the AAHA-AVMA feline preventative guidelines [19]. Yet, only $64 \%$ of veterinarians indicated that they perform/recommend preventative heartworm medication, only $80 \%$ gave/recommended behavioral advice and the least recommended procedures/treatments were socialization and "happy visits". Heartworm prevention and behavior counseling are included in the AAHA-AVMA feline guidelines. Although beyond the scope of this study it is likely that time constraints due to busy schedules and concerns that clients might be unwilling to pay for non-medical visits preclude offering these services. Expectations of cats are likely tied to people's knowledge about them, which may be influenced by their use of related information sources. Given that veterinarians were identified as the most trusted and accessible sources of information on cats' needs, they have the possibility to influence visit expectations. However, the low percentage of the general population respondents selecting veterinarians as a trusted and accessible source, suggests either that other sources may be outcompeting veterinarians or that people cannot readily identify good resources for information on cats.

Some interesting discrepancies were observed between the public's and veterinarians' beliefs about cats, which have potential cat welfare implications. While the finding that more general respondents listed convenience as an acceptable reason to relinquish a cat than veterinarians was not surprising, their higher selection that it is never acceptable to relinquish a cat was unanticipated. Veterinarians' expertise with cat health and welfare likely may explain why they were more neutral or inclined to agree that "it is difficult to interpret cat behavior", "cats tolerate pain well", and "cats are less expensive to maintain than other animals" than general respondents. As the latter statement may reflect public expectations of low cat care costs that may be unrealistic, further exploration of what owners anticipate relative to expenditures may be useful to ensure cat 
health and well-being.

Both veterinarian and the general public tended toward agree regarding most statements relative to cats' needs, although vets agreed more strongly. However, it should be noted that the idea that cats need to go on practice runs to clinics, which was supported more strongly by veterinarians, contradicts the result that few clinicians actually recommended or promoted this via "happy visits". The finding that veterinarians disagreed more with the statements, "It is easy to see when cats are in pain", and "It is more important to address cats' physical needs than their behavioral needs" compared to the general population, probably reflects other key knowledge differences with significant implications for cat care. For example, those without sufficient training to identify subtle indicators of pain in cats may incorrectly presume its absence, resulting in compromised well-being for some cats. Likewise, the idea that cats' physical needs take priority over their behavioral needs may jeopardize some cats.

While knowledge of an agreement on cat care needs appeared to be generally well aligned between members of the public and veterinarians, there was much less consistency on attitudes and confidence relative to cat/veterinarian interactions. Although both groups had similar responses to, "If a [my] cat has a behavioral problem I am confident that I [my vet] will know how to address it" and "I [my vet] provide[s] useful resources on cat behavior" neither group strongly agreed with these statements. These results are understandable since behavior is still a relatively new area of specialty. Perhaps some veterinarian respondents were not as comfortable with behavioral medicine as they were with physical aspects. Consistent with this suggestion, general respondents and veterinarians showed stronger agreement that "If a [my] cat has a health problem I am confident that I [my vet] will know how to address it" and "I [My vet] provide[s] useful resources on cat health". These findings are important given the observation that behavioral issues were among the top reasons for relinquishing cats [7] and that risk factors associated with reduced relinquishment of cats included regular provision of veterinary care, and understanding of cat behavior [6].

Opportunities exist for improvement in perceived competence and resource sharing on both behavioral and physical health aspects of cat welfare. An important point of disagreement that undoubtedly relates to knowledge and cultural shifts in veterinary medicine appears to underlie the higher veterinarian disagreement with the idea that "if a cat is fractious or difficult to handle during an exam, it is important to use whatever means (force, restraint) necessary to complete the exam." This finding probably reflects increasing veterinary practitioner knowledge about and focus on low stress handling of cats. Low stress handling may promote safer handling, decreased fear in cats and more generally "cat friendly" clinic practices [20] but cat owners may not yet be aware of these benefits.

As is the case for all studies, some limitations of the current investigation exist. 
Although, the convenience sample of veterinarians appeared reasonable given the AVMA findings, the over-representation of Purdue alumni may have affected the responses. Nevertheless, our findings indicate both characterizations and attitudes towards cats by veterinarians and the cat owning public that should favor their well-being, and contradictory behaviors and beliefs that potentially present challenges.

\section{Conclusion}

How people view cats may dictate their expectations and treatment of them, and ultimately, their welfare outcomes. It is therefore important to understand cat owners' attitudes, knowledge and beliefs about their companions and factors, such as sources of information people use to inform their perceptions of cats and their behavioral and physical needs. As veterinarians are often considered experts on animal welfare, it is important that they consider and offer services relating to all aspects of cat health, including behavior, and that they effectively educate clients on both behavior and health issues. Although this study's results indicate trends towards positive public and veterinarian attitudes toward and beliefs about cats, contradictory thought processes were revealed in beliefs and practices relative to cat care, and services offered by veterinarians. The perceived or actual lack of confidence in the ability of both groups to address cat's behavioral needs, suggests a need for improved knowledge about and access to cat behavior and health resources, and better communication between veterinarians and cat owning clients. Future studies need to be conducted to determine the best ways for the veterinary field to address gaps in opinions and knowledge between veterinarians and cat owners.

\section{Acknowledgements}

This work was supported by Morris Animal Foundation project number \#NCE-1-14077043.

\section{Conflict of Interest}

The authors declare there is no conflict of interest.

\section{References}

[1] Serpell, J.A. (2000) 9. Domestication and History of the Cat. In: Turner, D.C. and Bateson, P., Eds., The Domestic Cat. The Biology of Its Behaviour, 2nd Edition, Cambridge University Press, Cambridge, 179.

[2] Lawrence, E.A. (2003) Feline Fortunes: Contrasting Views of Cats in Popular Culture. The Journal of Popular Culture, 36, 623-635. https://doi.org/10.1111/1540-5931.00024

[3] Kellert, S.R. and Berry, J.K. (1980) Knowledge, Affection and Basic Attitudes toward Animals in American Society. Phase III. Fish and Wildlife Service (Dept. of Interior), Washington DC. 
[4] Perrine, R.M. and Osbourne, H.L. (1998) Personality Characteristics of Dog and Cat Persons. Anthrozoös, 11, 33-40. https://doi.org/10.2752/089279398787000904

[5] Zasloff, R.L. and Kidd, A.H. (1994) Loneliness and Pet Ownership among Single Women. Psychological Reports, 75, 747-752. https://doi.org/10.2466/pr0.1994.75.2.747

[6] Salman, M.D., New Jr., J.G., Scarlett, J.M., Kass, P.H., Ruch-Gallie, R. and Hetts, S. (1998) Human and Animal Factors Related to Relinquishment of Dogs and Cats in 12 Selected Animal Shelters in the United States. Journal of Applied Animal Welfare Science, 1, 207-226. https://doi.org/10.1207/s15327604jaws0103 2

[7] Salman, M. D., Hutchison, J., Ruch-Gallie, R., Kogan, L., New Jr., J. C., Kass, P.H. and Scarlett, J.M. (2000) Behavioral Reasons for Relinquishment of Dogs and Cats to 12 Shelters. Journal of Applied Animal Welfare Science, 3, 93-106. https://doi.org/10.1207/S15327604JAWS0302 2

[8] Hemsworth, P.H., Barnett, J.L. and Coleman, G.J. (1993) The Human-Animal Relationship in Agriculture and Its Consequences for the Animal. Animal Welfare, 2, 33-51.

[9] Kielland, C., Skjerve, E., Østerås, O. and Zanella, A.J. (2010) Dairy Farmer Attitudes and Empathy toward Animals Are Associated with Animal Welfare Indicators. Journal of Dairy Science, 93, 2998-3006. https://doi.org/10.3168/jds.2009-2899

[10] U.S. Census Bureau (2012) Statistical Abstract of the United States: 2012. http://www.census.gov/2010census/

[11] US Census Bureau (2010) DP-1 Profile of General Population and Housing Characteristics: 2010. 2010 Demographic Profile Data.

http://factfinder.census.gov/faces/tableservices/jsf/pages/productview.xhtml?pid=D EC 10 DP DPDP1\&prodType=table

[12] US Census Bureau (2008-2012) DP01: Selected Economics: 2008-2012. American Community Survey 5-Year Estimates. http://factfinder.census.gov/faces/tableservices/jsf/pages/productview.xhtml?pid=A CS 12 5YR DP03\&prodType=table

[13] StataCorp (2015) Stata Statistical Software: Release 14. StataCorp LP, College Station.

[14] AVMA (2015) Market Research Statistics: US Veterinarians 2015.

[15] CHWS (2013) 2013 US Veterinary Workforce Study: Modeling Capacity Utilization. AVMA.

[16] Cohen, S.P. (2002) Can Pets Function as Family Members? Western Journal of Nursing Research, 24, 621-638. https://doi.org/10.1177/019394502320555386

[17] Walsh, F. (2009) Human-Animal Bonds II: The Role of Pets in Family Systems and Family Therapy. Family Process, 48, 481-499. https://doi.org/10.1111/j.1545-5300.2009.01297.x

[18] Ramón, M.E., Slater, M.R. and Ward, M.P. (2010) Companion Animal Knowledge, Attachment and Pet Cat Care and Their Associations with Household Demographics for Residents of a Rural Texas Town. Preventive Veterinary Medicine, 94, 251263. https://doi.org/10.1016/j.prevetmed.2010.01.008

[19] AAHA-AVMA (2016) AAHA-AVMA Feline Preventive Healthcare Guidelines.

[20] Rodan, I. (2010) Understanding Feline Behavior and Application for Appropriate Handling and Management. Topics in Companion Animal Medicine, 25, 178-188. https://doi.org/10.1053/j.tcam.2010.09.001 
Submit or recommend next manuscript to SCIRP and we will provide best service for you:

Accepting pre-submission inquiries through Email, Facebook, LinkedIn, Twitter, etc. A wide selection of journals (inclusive of 9 subjects, more than 200 journals)

Providing 24-hour high-quality service

User-friendly online submission system

Fair and swift peer-review system

Efficient typesetting and proofreading procedure

Display of the result of downloads and visits, as well as the number of cited articles

Maximum dissemination of your research work

Submit your manuscript at: http://papersubmission.scirp.org/

Or contact ojvm@scirp.org 